This investigation was supported by a grant from the Medical Foundation, Inc., and by the General Research Support Grant of Boston City Hospital. We thank Dr. George D. Snoll, of the Jackson Laboratory, for advice on the genetic aspects of this investigation, and also Prof. Gerhard Schmidt, of Tufts Medical School, for advice on the procedures involving lipid chemistry.

ARnold E. Reif

Joan M. Allen

Biochemistry Section, Department of Surgery,

Tufts University School of Medicine, and the First (Tufts) Surgical Service,

Boston City Hospital, Boston, Massachusetts.

${ }^{1}$ Old, L. J., Boyse, E. A., and Stockert, E., J. Nat. Cancer Inst., 31, 977 (1963).

${ }^{2}$ Old, L. J., and Boyse, E. A., Ann. Rev. Med., 15, 167 (1964).

${ }^{3}$ Reif, A. E., and Allen, J. M. V., Nature, 200, 1332 (1963).

' Reif, A. E., and Allen, J. M. V., J. Exp. Med., 120, 413 (1964).

${ }^{8}$ Reif, A. E., and Allen, J. M. V., Nature, 203, 886 (1964).

${ }^{6}$ Möller, G., J. Immunol., 86, 56 (1961).

'Amos, D. B., Zumpft, M., and Armstrong, P., Transplantation, 1, 270 (1963).

${ }^{8}$ Möller, E., and Möller, G., J. Exp. Med.,115, 527 (1962)

'Winn, H. J., Ann. N.Y. Acad. Sci., 101, 23 (1962).

${ }^{10}$ Folch, J., Lees, M., and Sloan Stanley, G. H., J. Biol. Chem., 226, 497 (1957).

${ }^{11}$ Hogeboom, G. H., in Methods in Enzymology, edit. by Colowick, S. P., and Kaplan, N. O., 1 (Academic Press, New York, 1955).

${ }_{12}$ Weiner, L. B., and Osserman, K. E., Ann. N.X. Acad. Sci. (in the press).

\section{Mouse Nervous Tissue Iso-antigens}

MUCH work has been done on experimental autoimmunization with nervous tissues, and the relation of the resulting pathology to that found in demyelinative diseases of the human nervous system ${ }^{1}$. Furthermore, the existence of organ-specific lipid haptens has long been recognized; recently, Joffe, Rapport and Graf have identified one of these haptens as a galactocerebroside ${ }^{2}$. No strain-specific iso-antigens were described by these authors ${ }^{1,2}$

We recently described two strain-specific iso-antigens, $\theta-A K R$ and $\theta-C 3 H e B / F e$, one or the other of which is present at a high concentration in adult brain and thymus of all mouse strains that were tested ${ }^{3,4}$. In new-born mice of the four strains investigated, these antigens were found at a high concentration only in thymus; neonatal brain contained between 1 and 3 per cent of the antigen concentration found in adult brain. Thus, the two antigens appeared to originate either in thymus or in closely related cellular precursors. These $\theta$-iso-antigens were present at much lower concentrations in lymph node lymphocytes, splenic lymphocytes, appendix, lung and liver. Some leukaemias from $A K R$ mice possessed, a high content of the $\theta \cdot A K R$ iso-antigen, while others, apparently of non-thymic origin, possessed a low content. These data were obtained by use of immune cytolysis and of a quantitative absorption procedure ${ }^{4}$.

In the present investigation, the same methods but more potent iso-antisera were used. Results of absorption experiments are expressed as the absorptive capacity per unit wet weight of brain. Since the iso-antisera used showed high specificity in their absorption by different tissues, absorptive capacity is taken to parallel the content of $\theta$-iso-antigens ${ }^{4}$.

The appearance of $\theta$-iso-antigens in brain of three strains of mice (Fig. 1) paralleled the histological ${ }^{5,6}$ and physiological ${ }^{7}$ maturation of mouse brain. The $\theta$-iso-antigens remained at very low levels for the first 4 days after birth. Between 10 and 20 days of age, the antigen content rose from approximately 15 to 62 per cent of the adult-level, which was reached at 5-6 weeks of age (Fig. 1).

In addition, groups of two $\mathrm{C} 3 \mathrm{HeB} / \mathrm{Fe}$ mice aged 14 , $18,33,57$ and 81 weeks were investigated for antigen changes. All mice were male except for the youngest group. The mean relative content of $\theta-\mathrm{C} 3 \mathrm{HeB} / \mathrm{Fe}$ isoantigen per unit wet weight of brain was $100,99,87,93$

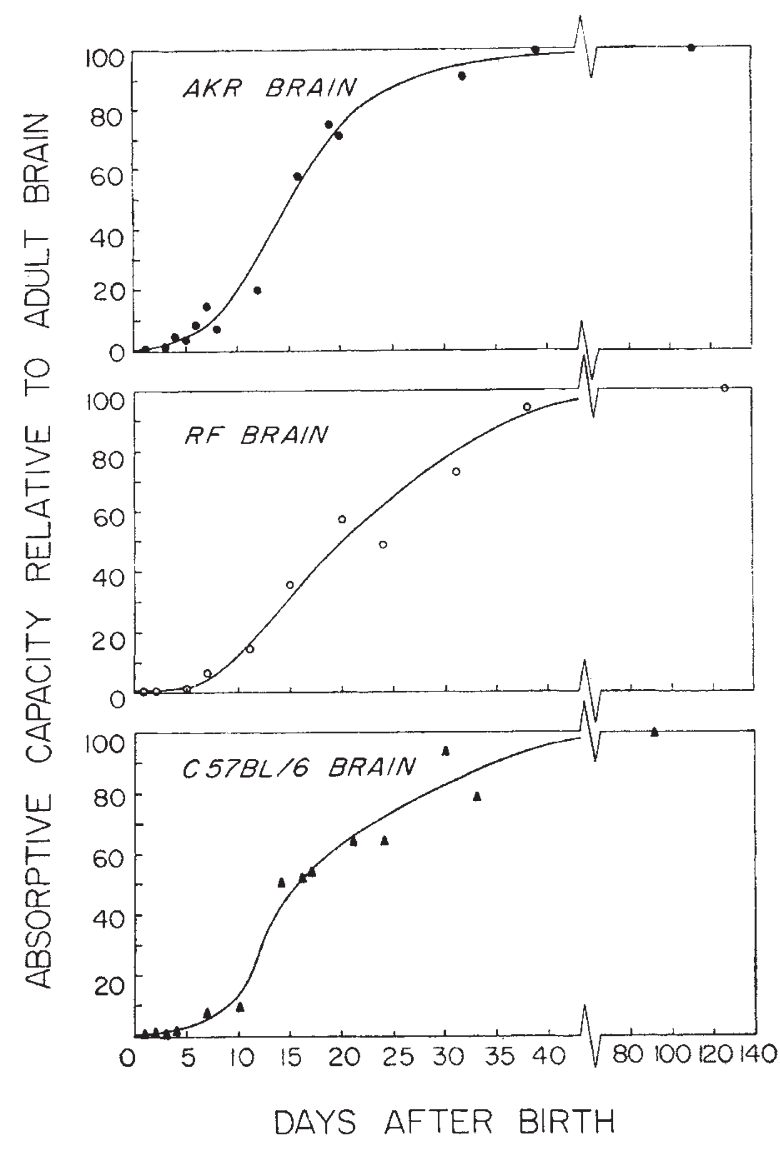

Fig. 1. Development of the $\theta$-iso-antigens in brain of three strains of mice. The absorptive capacity per unit wet weight of brain was determined for $A K R$ and $R F$ mice with $C 3 B E B / F e$ iso-antiserum to $A K R$ thymocytes, and for $C 57 B L / 6$ mice with $A K R$ iso-antiserum to $C 3 H e B /$

and 101 per cent, respectively. Thus, no significant change in antigen content was observed during adulthood.

Previously, we reported that immunological maturation of brain occurs in four strains of mice: $A K R, C 57 B L$, $I C R$ Swiss and $A$. This finding has now been extended to eight additional strains: $C 3 \mathrm{HeB} / \mathrm{Fe}, \mathrm{C} 3 \mathrm{H} / \mathrm{DiSn}, \mathrm{C} 57 \mathrm{~L}$, $C 57 B L / 6, C 58, D B A / 1, R F$ and $S W R$. Neonatal brain averaged 0.8 per cent of the content of $\theta$-iso-antigen in adult brain of these eight strains. Since no exceptions have been found, the presence of $\theta$-iso-antigens in mouse brain, and their development from low levels at birth to high levels in young adulthood, appear to be general phenomena in mice. These results suggest the possibility that analogous iso-antigens may exist in other species including man, and may be involved in auto-immune diseases of the nervous system ${ }^{1}$.

This investigation was supported by a grant from the Medical Foundation, Inc., and by the General Research Support Grant of Boston City Hospital.

Arnotd E. Rere JoAn M. Allen

Biochemistry Section, Department of Surgery, Tufts University School of Medicine, and the First (Tufts) Surgical Service,

Boston City Hospital, Boston, Massachusetts.

${ }^{1}$ Cruickshank, B., in Clinical Aspects of Immunology, edit. by Gell, P. G. H., and Coombs, R. R. A., 663 (Blackwell, Oxford, 1963).

${ }^{2}$ Joffe, S., Rapport, M. M., and Graf, L., Nature, 197, 60 (1963).

${ }^{3}$ Reif, A. E., and Allen, J. M. V., Nature, 203, 886 (1964).

${ }^{4}$ Reif, A. E., and Allen, J. M. V., J. Exp. Med., 120, 413 (1964). ${ }^{5}$ Kobayashi, T., Inman, O., Buno, W., and Himwich, H. E., in Rec. Adv.
Biol. Psychiat., edit. by Wortis, J., 5, 293 (Plenum Press, New York, Biol.

'Kobayashi, T., Amer. J. Physiol., 204, 343 (1963).

'Uzman, L. L., and Rumley, M. K., J. Neurochem., 3, 171 (1961). 